\title{
Medallions of Huviška as pictorial evidence of pre-Islamic lamellar helmets
}

\author{
https://doi.org/10.34739/his.2019.08.01
}

\begin{abstract}
In the current paper the author discusses headgear represented on Kušān medallions showing the bust of King Huviška. Most likely those medallions are depicting pre-Islamic lamellar helmets, well known from for example on the Sasanian, Būsetūn capital currently held in Tạq-e Bostān Museum, Iran. The author will try to compare the presented lamellar constructions with known finds of such helmets of the pre-Islamic era.
\end{abstract}

Key words: Lamellar helmets, Armour, Kushan, Sasanian, pre-Islamic

Zar Tepe is one of the more important archaeological sites of the lower Sorkān Daryā basin, Uzbekistan. It is situated about $25 \mathrm{~km}$ to the northwest of Termed and $4 \mathrm{~km}$ south of Angor village. The main site covered a square area of sixteen hectares. The town was defended by fortification walls flanked by semi-circular towers with a citadel located in one of the corners. The site was first explored by L.I. Al'baum in 1949-1952. Then, in the autumn of 1972, a new expedition under V.M. Masson started more extensive excavations at the site. The city was founded shortly before the Kušān Period, then flourished within this period. However, occupation of the site seems to have lasted until the Hephthalite period $\left(5^{\text {th }}-6^{\text {th }} \text { centuries }\right)^{1}$. During the excavations carried out in 1975-1976 a bronze medallion was discovered. It was published by V.A. Zavialov in $1979^{2}$, when it was dated to the $2^{\text {nd }} \mathrm{CE}$, and it now forms the basis for the following paper.

The object is a round medallion which depicts the figure of the king facing to the left (in profile). Huviška is shown wearing a form of headgear, often identified as segmented, which is most likely a helmet of spangenhelm construction ${ }^{3}$ (Fig. 1). However, after closer examination of the other representations of the Kušān King on

* ORCID iD 0000-0002-3112-0043. atakan-al-vefa@wp.pl; Institute of History and International Relations, Faculty of Humanities. The results of the research carried out under the research theme No. 204/17/MN were financed from the science grant granted by the Ministry of Science and Higher Education.

${ }^{1}$ MASSON 1974: 3-5.

${ }^{2}$ ZAVIALOV 1979: ris. 8 .

${ }^{3}$ ZAVIALOV 1979: 150-151, ris. 8, NIKONOROV 1997: 14, 69, FIg. 37f; KUBIK 2016: 89-90; 2017: 90-91. 
medallions the author comes to a completely different conclusion regarding the interpretation of the helmet worn by Huviška.

We start our studies with one fundamental question. Is the king really wearing a helmet? We have to state here that, with the exception of the supposed helmet, it is difficult to see any other form of body armour here. Nevertheless, the answer remains yes, it is very likely that we can see a helmet on on Huviška's head. This statement is not based only on the presence of Kušāno-Seleukid rulers' busts along with other aspects of Hellenistic art where, for example, we can see a warrior wearing only a helmet, without any body armour being present, as for example on representations of the Goddess Athena. We can also attempt to prove this point by correlating such depictions with later representations of lamellar helmet and with the construction details known from existing lamellar helmets from archaeological finds.
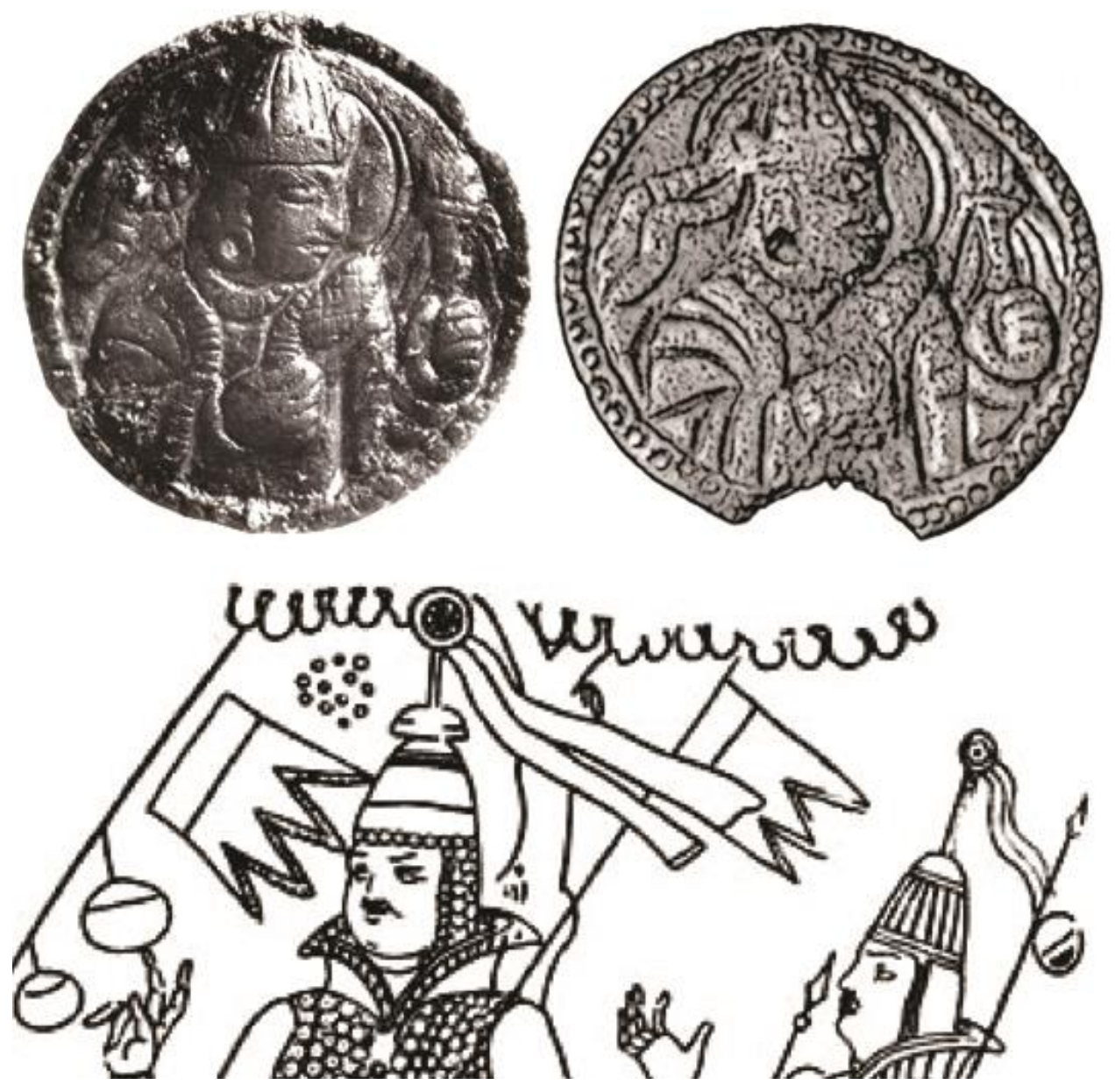

Fig. 1. From the upper left: Huviška depiction, $2^{\text {nd }} \mathrm{CE}$, Department of Coins and Medals, The British Museum, after: GÖBL 1963: Fig. 1, Huviška depiction, $2^{\text {nd }}$ CE. Zar Tepe medallion, drawing by author, Kizil so called Cave of the Painter, turn of the $3^{\text {rd }} / 4^{\text {th }}$ CE $-4 / 44^{\text {th }}$ CE, after: LE COQ 1925: Fig. 50. 
First of all, we know that there is a strong connection between later representations such as the figurative decorations on capitals from Bīsotūn, currently held at Tâaq-e Bostān and representations on the reverse of the coins of Kosrow II, sometimes known as the Anāhitā type ${ }^{4}$. Even if we are dealing with a heavily armored warrior, as in the case of a Bīsotūn capital ${ }^{5}$, on the so called Anāhitā depictions we cannot see any form of body armor nor any other military objects. It seems that in both cases a lamellar helmet is significant in the identification of the role of the personage. It is very likely that a similar relation was also preserved in subsequent early Islamic depictions where some of what might be called the Bīsotūn type (in the same pose ${ }^{6}$, and wearing a lamellar helmet) personages, could be seen both in heavily armored warriors (statuette from Hirbat al-Mafğar, currently held in Rockefeller Museum, Jerusalem $^{7}$ ) or without any form of body armour (Falconer silk depiction, currently held in Bastan Museum in $\operatorname{Tehran}^{8}$ ). We can state then that in Iranian art the representation of lamellar helmet could been included as an attribute of victory ${ }^{9}$ or of royal dignity even by unarmored personage.

Currently we know of several depictions of similar headgear in Kušān depictions. This is despite the fact that the obscure representation of the helmet presented on the Zar Tepe medallion could be identified as a spangenhelme type helmet (made of four or more pieces conjoined with metal strips) as presented, for example, on Pratișthāna or Nāgārjunikoṇụa figurines ${ }^{10}$. Correlation between the mentioned medallion and some other medallions published by R. Göbl in $1963^{11}$ or the one published by K. Tanabe in 1983, left no place for further speculations on the subject of the construction of the Zar Tepe helmet. The first medallion under discussion, held in the Department of Coins and Medals of the British Museum, London, shares the same Huviška representation with the Zar Tepe medallion (Fig. 1). However, details of the king's headgear depiction are far better preserved. The visible half of the helmet consists of multiple segments of the same width, this being the same construction that we can also observe on the other depiction presented by K. Tanabe in $1983^{12}$. Another very interesting feature can be observed on top of those headgears, where there is clearly a loop at the ending of the finial with decorative ribbons fluttering behind those personages. It is very interesting to note that such form of helmets - lamellar construction with a finial ended with some sort of loop with a decorative ribbons fluttering behind a warrior - could be observed on later Central

\footnotetext{
${ }^{4}$ SKUPNIEWICZ 2017: 211.

${ }^{5}$ SKUPNIEWICZ 2007: 9-28.

${ }^{6}$ SKUPNIEWICZ 2017: 211-212.

${ }^{7}$ NICOLLE 1976: 13, 2009: 96; KUBIK 2018a: 32-33.

${ }^{8}$ KUBIK 2018a: 37-38.

${ }^{9}$ SKUPNIEWICZ 2017: 217.

${ }^{10}$ ROSENFIELD 1967: Fig. 157; KUBIK 2016: 89; 2017a: 90.

${ }^{11}$ GÖBL 1963: 137.

12 TANABE 1983: Fig. I-A.
} 
Asian depictions dated to the turn of the $3^{\text {rd }} / 4^{\text {th }} \mathrm{CE}$ - till the $4 / 4$ of the $4^{\text {th }} \mathrm{CE}^{13}$, namely in so called the Cave of the Painter of Kizil Caves (Fig. 1) ${ }^{14}$. Such a form of loop is also known from a helmet discovered near the village of Kalkni (rus. Калкни) in the Republic of Dagestan, Russian Federation ${ }^{15}$. Among the pieces of a helmet found there was a bowl form finial with small holes around the edge and a single hole in the center. In his reconstruction, B.M. Salihov proposed a loop at the ending of that finial, however we cannot see that feature on his drawing of the actual helmet fragments. Finial size: diameter $-8,4 \mathrm{~cm}$, high $-4,5 \mathrm{~cm}^{16}$. B.M. Salihovs drawings published in 1985 give no clear answers for the finial construction. To solve that problem, we need to look at other helmet finds of that type. Unfortunately, there is no single find of the Kušān period which gives us a chance to see how the ending of the finial (loop) was constructed. However, some rounded finials or their remains are still preserved, as in a Kipčakovo (rus. Кипчаково) helmet ${ }^{17}$ (Fig. 2) or ShaikhānDherī helmet $^{18}$, which allow us to suggest some indications of how it could look.
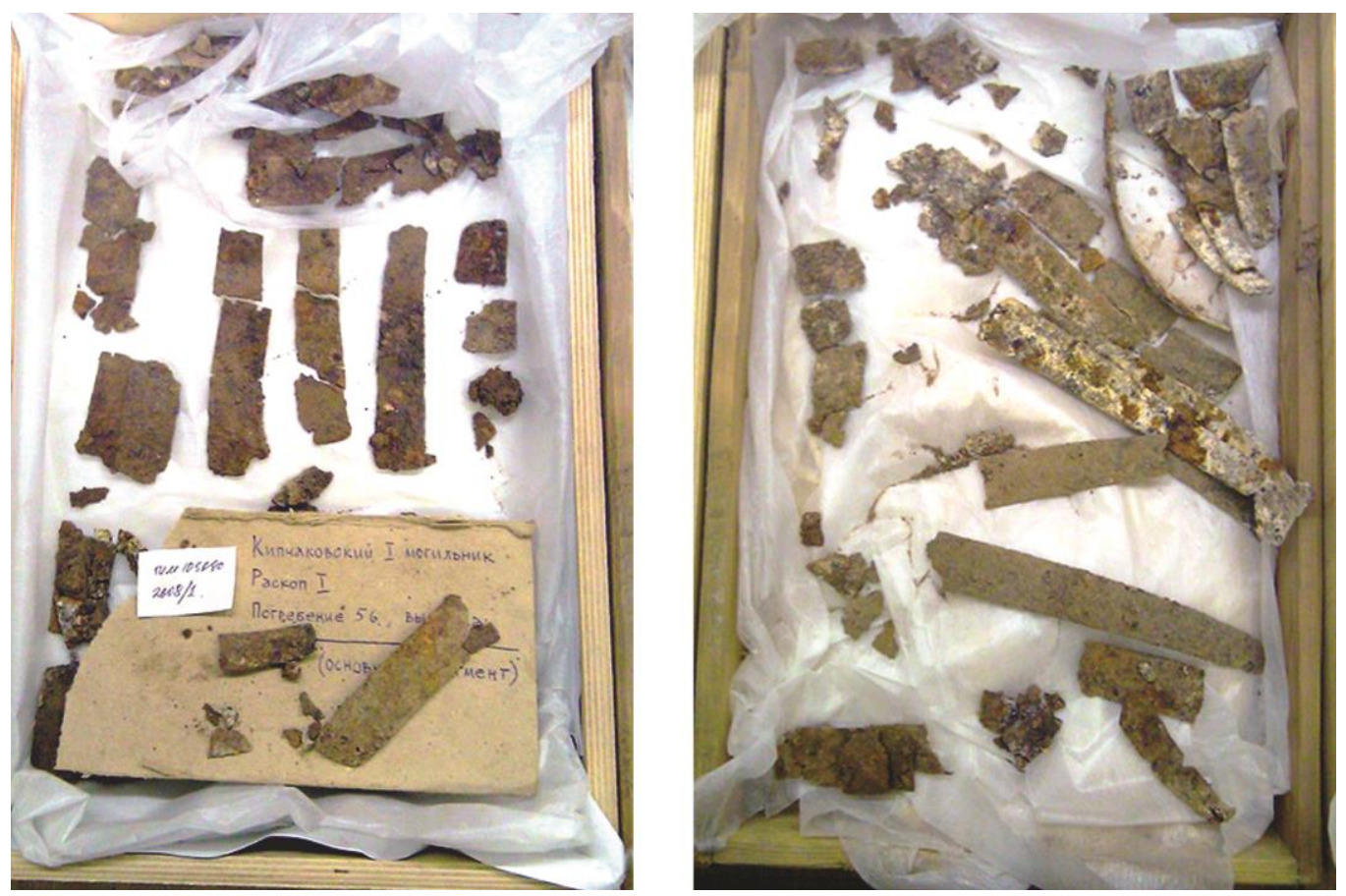

Fig. 2. Remains of the lamellar helmet from Kipčakovo (rus. Кипчаково), Ryazan Oblast (rus. Рязанская область) of the Russian Federation, $1^{\text {st }}-2^{\text {nd }} \mathrm{CE}$, photo courtesy O. Radjush.

\footnotetext{
${ }^{13}$ KUBIK 2018b: 147.

${ }^{14}$ LE COQ 1925: Fig. 50, KUBIK 2018b: 146-148.

${ }^{15}$ SALIHOV 1985: 167; KUBIK 2017b: 202.

${ }^{16}$ SALIHOV 1985: ris. V.1.

${ }^{17}$ ZUBOV 1999: 47, 2011: 68; ZUBOV, RADIUSH 2014: ris. 1.3.

${ }^{18}$ ALLCHIN 1970: 113-115; GORELIK 1982: 103; NIKONOROV 1997: 14, pl. 34 t; KUBIK 2017b: 197-198.
} 
Based on the almost untouched rounded finial of the Kušān lamellar helmet discovered in 1963 in the building or shrine D, in Shaikhān-Dherī, Chārsada ${ }^{19}$ we can state that such finials were hammered from the one piece of iron after which small holes were added around the edge as well as the main hole in the middle of the helmet finial. The central hole is about $2 \mathrm{~mm}$ width. The only possible solution to fix any loop there was to thrust a small rod in to the hole and then to flatten or bend it on the inner part of the finial. The same solution can be observed on later lamellar helmets from the Niederstotzingen type ${ }^{20}$ or, for example, on a helmet discovered in the Kursk Oblast (rus. Курская область), Russian Federation, published in 2014 by O.A. Radjush ${ }^{21}$ (Fig. 3). The Kursk helmet finial consist of the one-piece bowl with small holes around the edge and a main hole in a center.
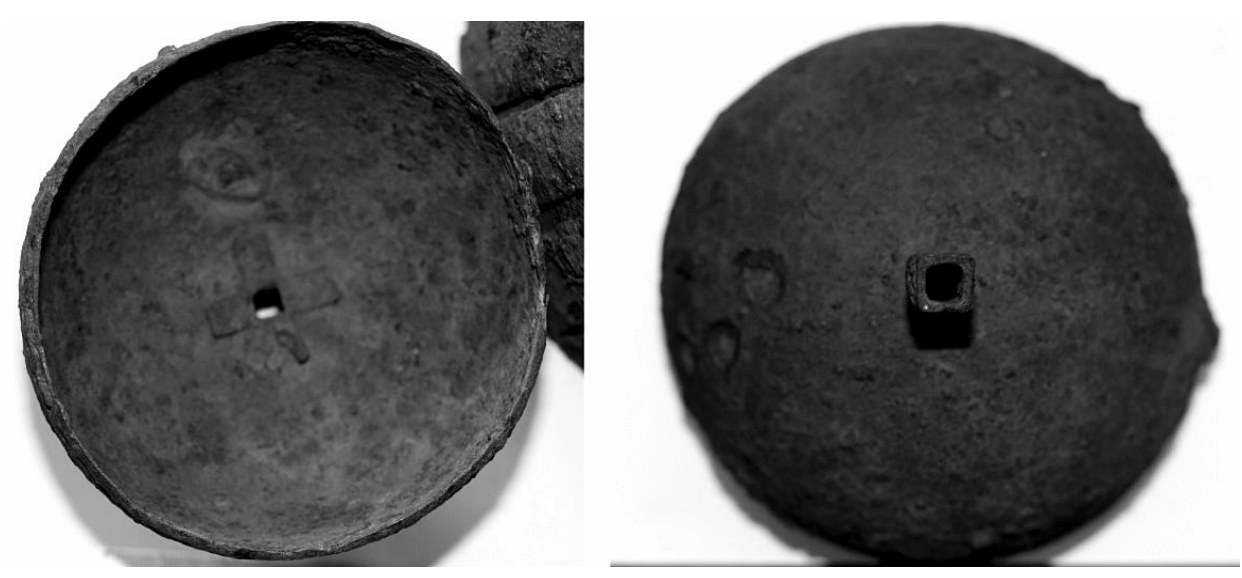

Fig. 3. View on the finial from the lamellar helmet, Kursk Oblast (rus. Курская область), Russian Federation, $6^{\text {th- }} 7^{\text {th }}$ CE. From the left: inner view, outer view, photo courtesy O. Radjush.

The ending is in a form of a tube with a square cross-section thrust into the central hole, after which its lower end was flattened on the inside of the helmet finial.

Among the medallions from a Japanese collection published by K. Tanabe ${ }^{22}$, one is extremely intriguing in the context of arms and armor studies (Fig. 4). The same personage, a Kušān king, is presented in a standing position. On his cheek there is a clearly visible line of ladder form scratches. This could indicate the use of segmented cheek pieces made of horizontally laced plates. Such a form of face protection was well documented among lamellar helmet finds from Kušān period, for example on helmets from:

\footnotetext{
${ }^{19}$ ALLCHIN 1970: 113-115.

${ }^{20}$ PAULSEN 1967: 133-137; WERNER 1988: abb. 15; JÄGER 2006: abb. 18.

${ }^{21}$ RADJUSH 2014: 41-42.

${ }^{22}$ TANABE 1983: 119-130.
} 
- Shaikhān-Dherī, Chārsada, Pakistan,

- Andreevskij kurgan, grave 50 (rus. Андреевский курган) in the north-eastern part of Mordova Republic (rus. Республика Мордовия) of the Russian Federation $^{23}$,

- Kipčakovo I burial (rus. Кипчаковский I курганно-грунтовый могильник), grave 56 in Ryazan Oblast (rus. Рязанская область) of the Russian Federation, Also, among the later evolutions of lamellar helmets ${ }^{24}$, as for example those from:

- Kerch necropolis, (rus. Керчь) ${ }^{25}$,

- Stara Zagora, Bulgaria ${ }^{26}$,

- Kursk Oblast (rus. Курская область), Russian Federation,

- Niederstotzingen, grave nr. 12, district of Heidenheim in Baden-Württemberg, southern Germany ${ }^{27}$.
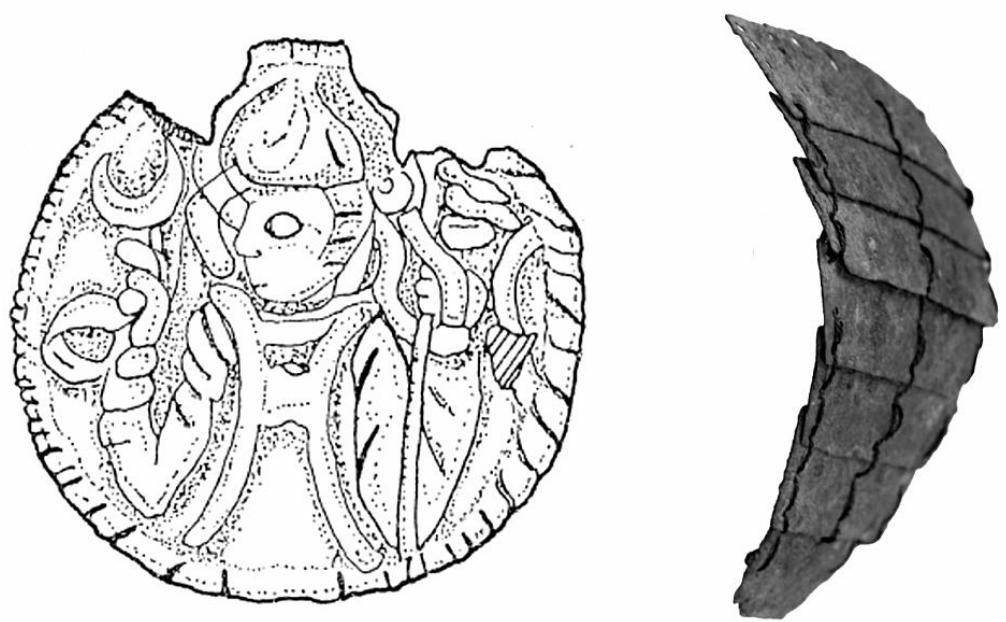

Fig. 4. From the left: Kušān seal, drawing by K. Tanabe, clearly visible segmented cheek cover, after: TANABE 1983: 122, Fig. 1, view on the well preserved segmented cheek piece from the lamellar helmet, Kursk Oblast (rus. Курская область), Russian Federation, $6^{\text {th- }} 7^{\text {th }}$ CE, photo courtesy O. Radjush.

It is likely that the possibility of a cheek piece representation on the Kušān medallion or seal is directly related to personage identification. In a standing position, the Kušān king's head becomes smaller and his physiognomy is obscured so that it was far easy to cover part of his face with armour. We cannot also exclude the possibility that some of the Kušān or later western Asian lamellar helmets had no cheek piece

\footnotetext{
${ }^{23}$ ZUBOV, RADJUSH 2014: 94-95, ris. 1.2.

${ }^{24}$ Those forms of cheek pieces are typical for western group of lamellar helmets see: KUBIK 2017b: 196197, for some further divagations on western and eastern lamellar helmet absorption see also: KAZANSKI 2019: 205-224.

${ }^{25}$ ARENDT 1932: 7.

${ }^{26}$ RADJUSH 2014: ris. 3c.

${ }^{27}$ PAULSEN 1967: 133-137.
} 
protection at all. Unfortunately, it is not possible to solve this problem based just on one obscure representation presented by K. Tanabe.

Segments in all lamellar helmets share one common characteristic. Their bottom parts are wider and they are nearly cone shaped (with some obvious deformations depending on helmet geometry). This is, of course, related to the simple geometry where the circumference of the bottom edge of the helmet is far bigger than the circumference of the edge of the helmet finial. This characteristic enables us to identify the fragment of lamellar from the Shaikhān-Dherī helmet ${ }^{28}$. It can also be observed on the Kipčakovo or Andreevskij kurgan helmets. It is similarly clearly visible on the Kušān medallions mentioned in the current paper (Fig. 2) as well as on later Iranian lamellar helmet representations ${ }^{29}$. There is just one exception to this rule, as far as is known to the current author. In southern Siberia, in the Ongudai administrative region of the Altai Republic (rus. Республика Алтай), Russian Federation, in Balyk-Sook I burial (rus. Балык-Соок) the grave of a warrior was discovered $^{30}$. Among the large stones numerous fragments of lamellar armour plates were discovered, some of them being identified as part of a lamellar helmet ${ }^{31}$. The problem with this identification came from a comparison with numerous known lamellar helmet pieces. The so-called Lamellar helmet from the Balyk-Sook I burial consisted of long plates in long rectangle form with some rounded upper part. The lacing system of the segments excludes the rounded geometry of the helmet. What is more, an extra line of lacing holes in the middle of the plates make them similar in form to the other plates from that burial which were clearly part of the body armor. A supposed helmet finial was created from having a multiple piece construction. There are still visible holes, randomly placed on the surface of that supposed 'finial', which have no equivalent in any known lamellar helmet. It is therefore highly likely that the so-called lamellar helmet from Balyk-Sook I burial was misunderstood and was in fact created from a part of the body armor. Nevertheless, to confirm that theory there it will be necessary to undertake an X-ray analysis of Balyk-Sook 'helmet' remains.

The last piece of information on lamellar helmet construction or decoration brought to us by the examined Kušān King representations is the decoration of the bottom part. We can clearly observe one element of decoration on a forehead part of the helmet. It is hard to say whether or not there was any sort of lower band or diadem. Decoration in the forehead part of a helmet makes them clearly related to helmets of another form of construction, namely the skeleton or frame helmet discovered in Kišpek kurhan 13 (rus. Кишпек), Kabardino-Balkar Republic (rus. Кабардино-Балкарская Республика), Russian federation. Its construction

\footnotetext{
${ }^{28}$ KUBIK 2017b: 197-198.

${ }^{29}$ KUBIK 2017b: 204-208.

${ }^{30}$ KUBAREV, KUBAREV 2003: 64-65.

${ }^{31}$ GORBUNOV 2003: 156.
} 
consists of a skeleton made of long spangs connected to the upper part of the helmet with a rivet while smaller pieces are attached to the carcass construction ${ }^{32}$.

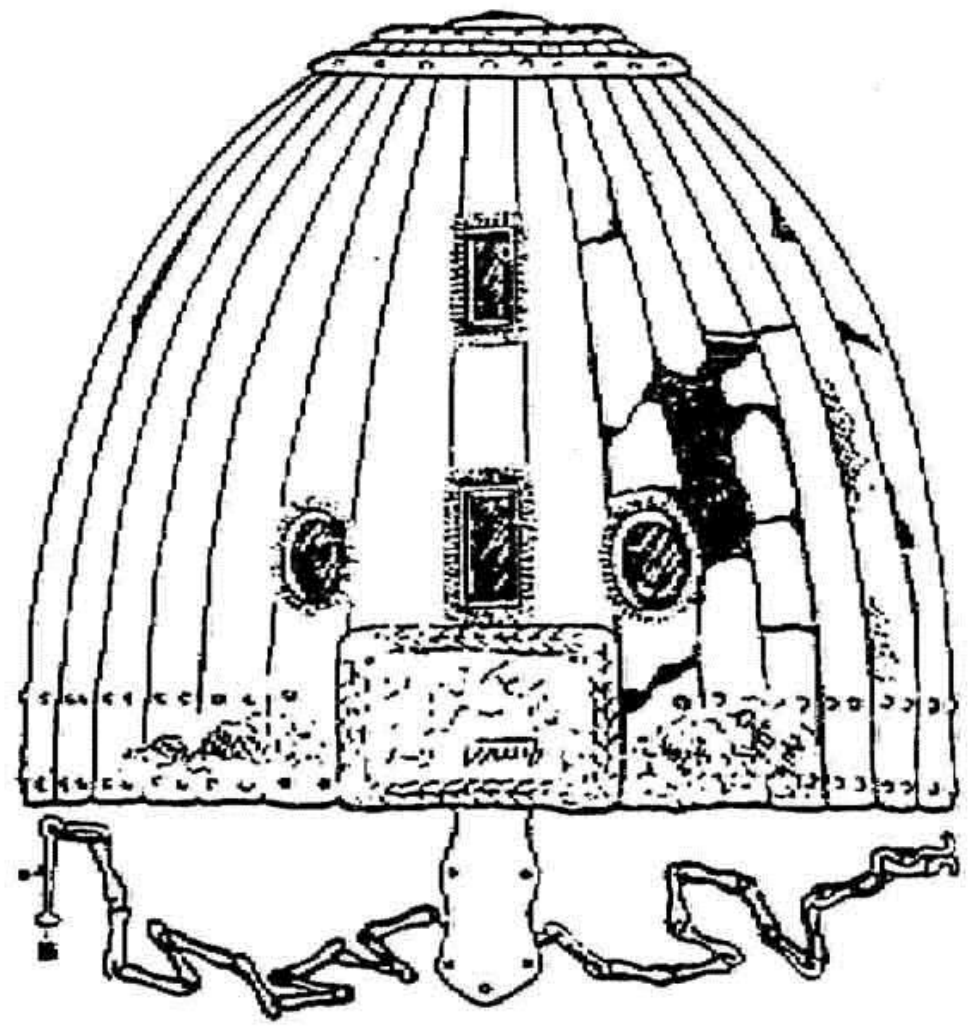

Fig. 5. Kišpek kurhan 13 helmet (rus. Кишпек), Kabardino-Balkar Republic (rus. Кабардино-Балкарская Республика), Russian federation, after: BETROZOV 1987: Fig. III.1.

Such constructions were popular among the Sarmatians in the northern Pontic region during $1^{\text {st }}-3^{\text {rd }}$ century $\mathrm{CE}^{33}$. The Kišpek helmet is unusual when we compare it with other skeleton helmets. The number of plates clearly has increased, giving impression of a lamellar construction, yet there is no connection between those segments. Just as on the Kušān representations. the main decoration was placed on a forehead part of the helmet. Here it includes gem stones and a possible rectangular bronze decorated plate which was found close to the helmet, as was proposed by R. Betrozov ${ }^{34}$. Such a form of decoration brings to mind not only Kušān lamellar helmet representations but also the mentioned lamellar helmet representation from Bīsetūn, where rectangular gem stones were placed around the bottom part of the helmet ${ }^{35}$. What is more, the bottom part of that helmet inner band was attached by

\footnotetext{
${ }^{32}$ MIKS 2009: abb. 4, SYMONENKO 2015a: ris. 75.

${ }^{33}$ MIKS 2009: 403,405, SYMONENKO 2015a: 215-230, SYMONENKO 2015 b.

${ }^{34}$ BETROZOV 1987: 34.

${ }^{35}$ KUBIK 2017b: 207.
} 
two rows of massive bronze rivets, looking like two rows of pearls, which were a typical form of decoration known from Sasanian $\operatorname{art}^{36}$. It should also be noted that the Bīsetūn helmet representation was decorated in a very similar form.

To conclude, the author suggests that depictions known from Kušān medallions of Huviška play an important role in the study on armour of pre-Islamic Western and Central Asia. The way of representing helmets, visible on those meallions, enables us to increase our knowledge on a topic of construction details of badly preserved archaeological finds of lamellar helmets of the pre-Islamic era. We can only hope that the number of similar findings will increase in the near future.

\section{Bibliography}

ALLCHIN F.R. (1970), 'A piece of scale armour from Shaikhan Dheri, Charsada', Journal of the Royal Asiatic Society 2, 113-120.

ARENDT W. (1932), 'Beiträge zur entstehung des Spangenharnisches. Ein alttürkischer Waffenfund aus Kertsch', Zeitschrift für Historische Waffen- und Kostümkunde 13, 49-55.

BETROZOV R.J. (1987), 'Kurgany gunnskogo vremieni u sela Kišpek', in Arkhrologičeskie issledovaniia nanovostroikakh Kabardino-Balkarii v 1972-1979 gg., 3, ed. V. A. KUZNETSOV, Nal'chik, 11-139.

GORBUNOV V.V. (2003), Voennoe delo naseleniya Altaya v III-XIV vv. Ch. I. Obronitel'noe voruženie (dospeh), Barnaul.

GORELIK M.V. (1982), 'Kušanskii dospieh', in Drevnya Indiya: Istoriko-kul'turnye svyazi, ed. G.M. BONGARD-LEVIN, Moskva, 82-112.

GÖBL R. (1963), 'Beiträge zur ikonographie der kušānkönige: Huviška', Central Asiatic Journal 8.2 (June), 135-142.

JÄGER U. (2006), 'Der griechisch-hellenistiche Muskelpanzer und sein Fortlaben in Zentralasien, 4. Jh. v. Chr. Bis 8./9. Jh. v. Chr.: Ein kurzer Beitrag zum rüstungstechnologichen Nachleben des Hellenismus in Zentralasien', in Arms and Armours as Indications of Cultural Transfer. The steppes and the Ancient World from Hellenistic Times to the Early Middle Ages, eds. M. MODE, J. TUBACH, Wiesbaden, 19-42.

KAZANSKI M.M. (2019), 'O Šlemah bospora kimeriyskogo rannevizantiyskogo vremienii: Tradičiya ili innovačiya', Bosporskie Issledovaniya 38, 205-224.

KUBAREV G.V., KUBAREV V.D. (2003), 'Noble Turk grave in Balyk-Sook (Central Asia)', Archaeology, Ethnology \& Anthropology of Euroasia 4.16, 64-82.

KUBIK A.L. (2016), 'Introduction to studies on late Sasanian protective armour. The Yarysh-Mardy helmet', Historia i Świat 5, 77-105.

KUBIK A.L. (2017a), Hetmy Azji Poludniowo-Zachodniej pomiędzy VI - VIII w.n.e. zarys problematyki, Siedlce.

KUBIK A.L. (2017b), 'Sasanian lamellar helmets', in Crowns, hats, turbans and helmets. The headgear in Iranian history volume I: Pre-Islamic Period, eds. K. MAKSYMIUK, G. KARAMIAN, SiedlceTehran, 195-210.

KUBIK A.L. (2018a), 'O wpływie sasanidzkich hełmów lamelkowych na sztukę wczesnego islamu', in Istoriâ religìj v Ukraïni: naukovij šoričnik, eds. O. KIRIČUK, M. OMEL'ČUK, Lviv, 30-41.

KUBIK A.L. (2018b), 'The Kizil Caves as a terminus post quem of the Central and Western Asiatic pearshape spangenhelm type helmets The David Collection helmet and its place in the evolution of multisegmented dome helmets', Historia i Świat 7, 141-156.

LE COQ von A. (1925), Bilderatlas zur Kunst und Kulturgeschichte Mittel-Asiens, Vol.1, Berlin.

${ }^{36}$ KUBIK 2017a: 47-53. 
MASSON V.M. (1974), 'Problema drevnego goroda i arkheologicheskiye pamyatniky severnoy Baktrii', in Drevnyaya Baktriya, ed. V.M. MASSON, Leningrad, 3-13.

MIKS Ch. (2009), 'Relikte eines frühmittelalterlichen Oberschichtgrabes?', Jahrbuch des RömischGermanischen Zentralmuseum Mainz 56, 395-538.

NICOLLE D. (1976), Early Islamic Arms and Armour, Madrid.

NICOLLE D. (2009), The Great Islamic Conquest AD 632-750, Westminster.

NIKONOROV V.P. (1997), Armies of Bactria 700 BC - 450 AD, 2, Stockport.

PAULSEN P. (1967), Alamanniche Adelsgräben von Niederstotzingen, I, Stuttgart.

RADJUSH O.A. (2014), 'Šlemy epohi pereseleniya narodov iz podneprov'ya', in Voinskie Tradičii $v$ Arhaeologičeskom Kontekste: ot pozdnego latena do pozdnego srednevekov'ya, ed. I.G. BURCHEV, Tula, 40-51.

ROSENFIELD J.M. (1967), The Dynastic Arts of the Kushans, Berkeley.

SALIHOV B.M. (1985), 'Kalkniyskiy mogilnik', in Drevnie kul'tury Severno-Vostočnogo Kavkaza, ed. M.M. MAMMAEV, Makhachkala, 167-187.

SKUPNIEWICZ P.N. (2007), 'Hełm wojownika przedstawionego na kapitelu w Tak-e Bostan', Acta Militaria Mediaevalia 3, 9-28.

SKUPNIEWICZ P.N. (2017), 'On the Helmet on the Capital at Țāq-e Bostān again', in Crowns, hats, turbans and helmets. The headgear in Iranian history volume I: Pre-Islamic Period, eds. K. MAKSYMIUK, G. KARAMIAN, Siedlce-Tehran, 211-222.

SYMONENKO O.V. (2015a), Sarmatskie vsadniki severnogo pričernomoria, Izd. 2. Kiev.

SYMONENKO O.V. (2015b), 'Sarmatian-Age helmets from Eastern Europe', in Archivum Euroasiae Medii Aevi. Festschrift for Thomas T. Allsen in Celebration of His $75^{\text {th }}$ Birthday, eds. P.B. GOLDEN, R.K. KOVALEV, A.P. MARTINEZ, J. SKAFF, A. ZIMONYI, Wiesbaden, 277-303.

TANABE K. (1983), 'Kushan Bronze Medallions from Japanese Collections (貴霜族の青銅製円形飾金具)', Bulletin of the Society for Near Eastern Studies in Japan 26.2, 119-130.

WERNER J. (1988), Adelsgräber von Niederstotzingen bei Ulm und von Bokchondong in Südkorea: Jenseitsvorstellungen vor Rezeption von Christentum und Buddhismus im Lichte vergleichender Archäologie, München.

ZAVIALOV V.A. (1979), 'Raskopki kvartala pozdnekušanskogo vremeni na gorodišče Zar-Tepe v 19751976 gg', Sovetskaya Archeologia 3, 141-154.

ZUBOV S.E. (1999), 'K probleme etnokulturnoy iterpretačii pamjatnikov andreevskogo-piseral'skogo tipa', in Issledovanija P.D. Stepanova I etnokulturna prochessy drevnosti i sovremiennosti: materialy mezhdunarodnoi naučnoy konferenčii posviašennoi 100-letniyu P.D. Stepanova, ed. N.M. ARSENT'EV, Saransk, 44-51.

ZUBOV S.E. (2011), Voinskie migračii rimskogo vremeni v Srednem Povolzh'e (I-III v.v.), Saarbrücken.

ZUBOV S.E., RADJUSH O.A. (2014), 'Šlemy Srednego Povolz'â v srednesarmatskoe vremya', in Sarmaty i vnešniy mir. Materialy VIII Vserossiyskoy (s mezhdunarodnym učastiem) naučnoy konferenčii «Problemy Sarmatskoi Arheologii i Istorii» IIJAL UNCH RAN, 12-15 Maya 2014 g., eds. L.T. JABLONSKIĪ, N.S. SABEL’EV, Ufa, 94-104. 